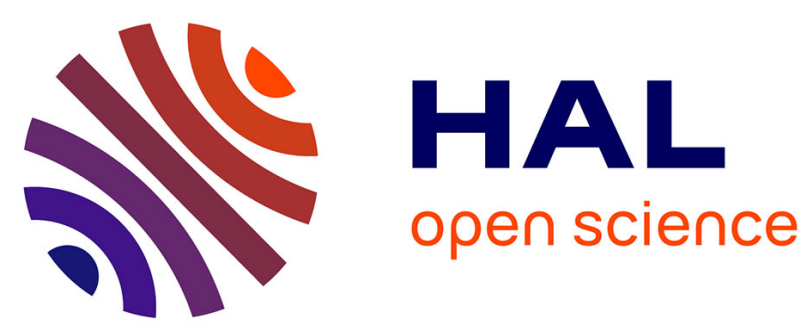

\title{
Characterization of whey proteins from Mongolian yak, Khainak, and Bactrian camel
}

B. Ochirkhuyag, Jean-Marc Chobert, Michèle Dalgalarrondo, Yvan Choiset, Thomas Haertlé

\section{- To cite this version:}

B. Ochirkhuyag, Jean-Marc Chobert, Michèle Dalgalarrondo, Yvan Choiset, Thomas Haertlé. Characterization of whey proteins from Mongolian yak, Khainak, and Bactrian camel. Journal of Food Biochemistry, 1998, 22, pp.105-124. hal-02687416

\section{HAL Id: hal-02687416 \\ https://hal.inrae.fr/hal-02687416}

Submitted on 1 Jun 2020

HAL is a multi-disciplinary open access archive for the deposit and dissemination of scientific research documents, whether they are published or not. The documents may come from teaching and research institutions in France or abroad, or from public or private research centers.
L'archive ouverte pluridisciplinaire HAL, est destinée au dépôt et à la diffusion de documents scientifiques de niveau recherche, publiés ou non, émanant des établissements d'enseignement et de recherche français ou étrangers, des laboratoires publics ou privés.

\section{(c)(2)}

Distributed under a Creative Commons CCO - Public Domain Dedication| 4.0 International 


\title{
CHARACTERIZATION OF WHEY PROTEINS-FROM MONGOLIAN YAK, KHAINAK, AND BACTRIAN CAMEL
}

\section{B. OCHIRKHUYAG'}

Institute of Chemistry

Academy of Sciences

Oulaanbaatar, Mongolia

\author{
AND \\ J.-M. CHOBERT ${ }^{2}$, M. DALGALARRONDO, Y. CHOISET \\ and T. HAERTLE
}

Laboratoire d'Etude des Interactions des Molécules Alimentaires

INRA, rue de la Géraudière

B.P. 71627, 44316 Nantes Cedex 3, France

Received for Publication May 21, 1997

Accepted for Publication September 25, 1997

\begin{abstract}
The composition of whey proteins from ruminant Mongolian domestic animals was analyzed and a comparative study between camel (Camelus bactrianus) and dromedary (Camelus dromedarius) was made. Whey proteins were separated by ion-exchange chromatography and identified by polyacrylamide gel electrophoresis, amino acid composition and $N$-terminal sequence determination. The main components of wheys of yak and khainak were nearly identical with their bovine counterparts. Three different forms of $\alpha$-lactalbumin were isolated in the whey of Camelus bactrianus and two from Camelus dromedarius. As shown by classical biochemical and immunological studies, $\beta$-lactoglobulin was absent from whey of both Camelus. Camel whey basic protein (CWBP), having no analogy with known milk and nonmilk proteins, was identified in the whey of Camelus bactrianus and Camelus dromedarius and its $N$-terminal sequence was determined.
\end{abstract}

1 Recipient of a fellowship from the Ministère des Affaires Etrangères, as an exchange between France and Mongolia.

${ }^{2}$ Corresponding author. E-mail: chobert@nantes.inra.fr, Fax: 33(0)2.40.67.50.84

Journal of Food Biochemistry 22 (1998) 105-124. All Rights Reserved.

- Copyright 1998 by Food \& Nutrition Press, Inc., Trumbull, Connecticut. 


\section{INTRODUCTION}

Whey is a coproduct of the dairy industry, produced in large amounts (about 130 millions tons per year; Zall 1992), from cheese or casein production. Whey proteins have many important techno-functional properties, including water binding, emulsification, gel formation, and have excellent nutritional quality. Whey proteins are excellent candidates for the development of new products. The growing interest in their functional use (Kim et al. 1987) stimulated the production of a wide range of whey protein products. Food products which include whey proteins due to their beneficial functional properties are beverages (solubility), confectionery (whippability), desserts (emulsification, whippability), dairy products (viscosity), meat products (fat-, water-binding), bakery products (heat stability), infant formula (low-allergenicity). Further utilization of whey proteins requires the implementation of more extensive strategies based upon compositional, physico-chemical and functional properties. As is well known, $\beta$-lactoglobulin and $\alpha$-lactalbumin are the two major whey proteins in milk. $\beta$-Lactoglobulin is the dominant whey protein in the milk of various species: bovidae (Palmer 1934), pig (Kessler and Brew 1970), horse (Bell et al. 1981), red deer (McDougall and Stewart 1976), donkey (Liberatori et al. 1979), sheep (Bell and McKenzie 1964), and goat (Préaux et al. 1979). In contrast, $\alpha$-lactalbumin is the dominant protein in rodent (Vilotte and Soulier 1992), llama (Cantisani et al. 1990), camel (Beg et al. 1985) and human whey (Brignon et al. 1985) and the milk of these species is probably devoid of $\beta$-lactoglobulin.

Conti et al. (1985) investigated Camelus dromedarius whey proteins by gel filtration on Sephadex G-100 and determined some of its components by electrophoresis. This study also revealed the presence of immunoglobulins and serum albumin in camel whey. Two variants of $\alpha$-lactalbumin were isolated and named $\alpha$-lactalbumin A and B. They show differences in their isoelectric point (5.1 and 5.3, respectively), amino acid composition and $\mathrm{N}$-terminal sequence. Beg et al. (1985) published the complete amino acid sequence of Camelus dromedarius $\alpha$-lactalbumin. Camel $\alpha$-lactalbumin has a molecular mass of 14.6 $\mathrm{kDa}$, contains 123 amino acid residues, and shows SDS-PAGE mobility like bovine $\alpha$-lactalbumin. Beg et al. $(1984,1986,1987)$ separated and characterized three new camel whey proteins. One of them has a molecular weight of 14.0 $\mathrm{kDa}$, contains 117 amino acid residues and is rich in cysteine/half cystine (16 half cystine residues). This new protein shows structural similarities with bovine $\beta$-casein $\mathrm{A} 2$ at its $\mathrm{N}$-terminal region. The second new camel whey protein consists of 64 amino acid residues and is a fragment of camel $\beta$-casein, homologous to the $\mathrm{C}$-terminal fragment of bovine $\beta$-casein. The third new camel whey protein found by Beg et al. (1987) has 112 amino acid residues, a molecular mass of about $15.0 \mathrm{kDa}$ and was named 'novel camel whey protein'. 
Cantisani et al. (1990) isolated a protein from llama whey with a molecular mass of $30 \mathrm{kDa}$ that was homologous to the 'novel camel whey protein' Sorensen and Petersen (1992) described a protein in the bovine proteose-peptone fraction with a molecular mass of $17.0 \mathrm{kDa}$, which displays homologous fragments to the 'novel camel whey protein'. The question, does $\beta$-lactoglobulin exist in camel whey? is still unsolved since Liberatori et al. (1979) observed antibodies with a cross-reactivity to bovine $\beta$-lactoglobulin in camel colostrum in higher titers.

The present work aims at characterizing the physico-chemical properties of the major whey proteins from Mongolian domestic livestock animals such as yak (the polymorphism of whey proteins from Mongolian cow and yak has been yet studied by Grosclaude et al. (1976, 1982)), khainak (hybrid of yak and cow) and Camelus bactrianus. Moreover, these whey proteins were compared with those of cow and Camelus dromedarius, which are well known.

\section{MATERIALS AND METHODS}

\section{Preparation of Whey Proteins}

Milk was collected as previously described (Ochirkhuyag et al. 1997). It was defatted by centrifugation at $37 \mathrm{C}, 4000 \mathrm{rpm}$ for $15 \mathrm{~min}$. Casein was precipitated at its isoelectric point ( $\mathrm{pH} 4.6$ ) by using $1 \mathrm{~N} \mathrm{HCl}$. After centrifugation, the resulting supernatant was dialyzed against distilled water and then freeze dried. Samples were kept at $-20 \mathrm{C}$ until used.

\section{Fractionation of Whey Proteins}

The individual whey proteins were purified by ion-exchange chromatography on a DEAE-Sephacel (Pharmacia, Orsay, France) column $(26 \mathrm{~mm}$ i.d. $\times$ $26 \mathrm{~cm}$ ) by applying a gradient (Fig. 1) from buffer A $(50 \mathrm{mM}$ Tris- $\mathrm{HCl}, \mathrm{pH}$ $8.0,5 \mathrm{mM} \mathrm{CaCl}$ ) to buffer B (50 mM Tris-HCL, $\mathrm{pH} 8.0,5 \mathrm{mM} \mathrm{CaCl} 2,1 \mathrm{M}$ $\mathrm{NaCl}$ ), at room temperature, at a flow rate of $2.5 \mathrm{~mL} / \mathrm{min}$. The ion-exchange chromatography was carried out on an Econo system (Bio-Rad, Ivry sur Seine, France).

\section{High Performance Liquid Chromatography (HPLC)}

Analytical and preparative reversed-phase HPLC separations were performed on a Waters instrument (Waters Associates, Millford, MA) equipped with an interface module system, assisted by a chromatography work station Maxima 820. Analytical RP-HPLC of whey proteins was carried out on a Nucleosil $5 \mathrm{C}_{18}$ column $(4.6 \mathrm{~mm}$ i.d. $\times 25 \mathrm{~cm})$, at a flow rate of $1 \mathrm{~mL} / \mathrm{min}$. A LiChroCART $100 \mathrm{C}_{18}(10 \mathrm{~mm}$ i.d. $\times 25 \mathrm{~cm})$ column was used for preparative 
run, at a flow rate of $2 \mathrm{~mL} / \mathrm{min}$. Absorbency was recorded at $214 \mathrm{~nm}$. Buffers and gradients were used according to Pearce (1983).

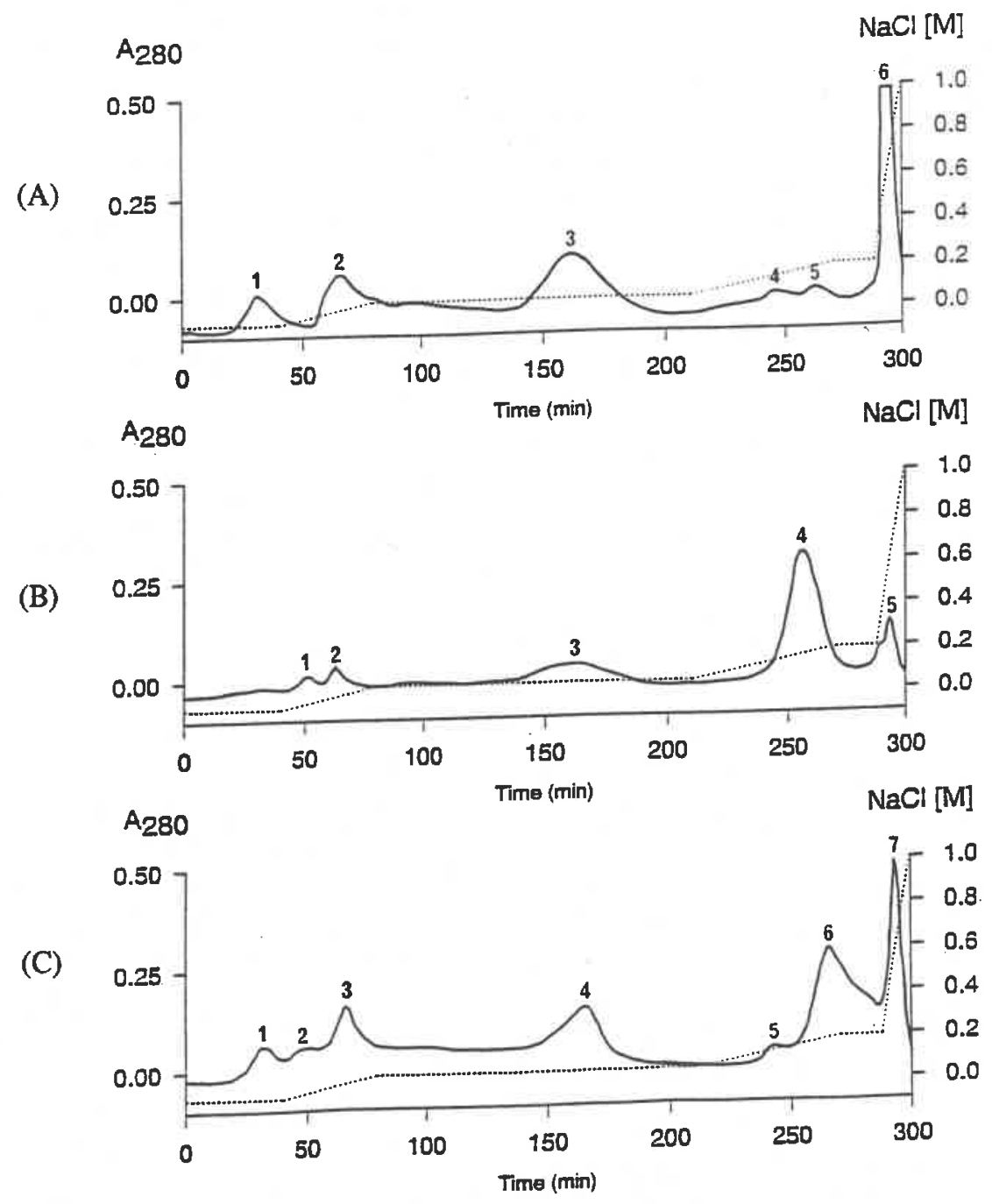

FIG. 1. FRACTIONATION OF THE TOTAL WHEY PROTEIN FRACTIONS OF BOVINE (A), YAK (B), AND KHAINAK (C) MILK BY ION-EXCHANGE CHROMATOGRAPHY ON DEAE-SEPHACEL

Fractions $(6.8 \mathrm{~mL})$ were collected at a flow rate of $150 \mathrm{~mL} / \mathrm{h}$. 


\section{High Perfusion Liquid Chromatography}

Ion-exchange perfusion liquid chromatography was carried out on a Biocad Sprint system (PerSeptive Biosystems, Voisins le Bretonneux, France). A HQ Poros $20 \mu(4.6 \mathrm{~mm}$. i.d. $\times 100 \mathrm{~mm})$ column was used for anion-exchange purification. After equilibrating the column in buffer A ( $25 \mathrm{mM}$ Tris- $\mathrm{HCl}, \mathrm{pH}$ $8.5,5 \mathrm{mM} \mathrm{CaCl}$ ), separations were carried out at a flow rate of $5 \mathrm{~mL} / \mathrm{min}$, using a linear gradient from 0 to $30 \% \mathrm{~B}(25 \mathrm{mM}$ Tris- $\mathrm{HCl}, \mathrm{pH} 8.5,5 \mathrm{mM}$ $\left.\mathrm{CaCl}_{2}, 1 \mathrm{M} \mathrm{NaCl}\right)$ over 20 column volumes. A HS-Poros $20 \mu(4.6 \mathrm{~mm}$. i.d. $\times$ $100 \mathrm{~mm}$ ) cation-exchange column was used to purify lactoferrin and camel whey basic protein. The column was equilibrated with 5 column volumes of buffer $\mathrm{C}$ (25 mM Tris- $\mathrm{HCl}, \mathrm{pH} 7.5,5 \mathrm{mM} \mathrm{CaCl}$ ) at a flow rate of $5 \mathrm{~mL} / \mathrm{min}$, and separation was performed, using a linear gradient from 0 to $80 \%$ of D $(25 \mathrm{mM}$ Tris- $\mathrm{HCl}, \mathrm{pH} 7.5,5 \mathrm{mM} \mathrm{CaCl}, 1 \cdot \mathrm{M} \mathrm{NaCl}$ ) within 20 column volumes. Absorbencies were recorded at 280 and $214 \mathrm{~nm}$.

\section{Polyacrylamide Gel Electrophoresis (PAGE)}

SDS-PAGE was performed in a vertical mini slab gel apparatus Protean II (Bio-Rad). The SDS-PAGE was carried out according to the method of Laemmli (1970), at room temperature. The running gel and the stacking gel contained $15 \%$ and $4 \%$ acrylamide, respectively. Silver staining of the gel was carried out according to Nesterenko et al. (1994) while staining with Schiff's reagent was done according to Groves et al. (1992).

\section{Amino Acid Composition Analysis}

The purified individual whey proteins in their native and oxidized forms (with performic acid) were hydrolyzed with $6 \mathrm{~N} \mathrm{HCl}$ (Pierce) for $24 \mathrm{~h}$ at $110 \mathrm{C}$, in a Pico-Tag station (Waters). The amino acids were derivatized with phenylisothiocyanate (PITC) according to the method of Bidlingmeyer et al. (1984) and separated by RP-HPLC on a Pico-Tag $\mathrm{C}_{18}$ column (3.9 mm i.d. $\times$ $15 \mathrm{~cm})$. The column was equilibrated with solvent $\mathrm{A}\left(94 \% 0.14 \mathrm{M} \mathrm{CH}_{3} \mathrm{COONa}\right.$, $0.5 \mathrm{~mL} \mathrm{TEA} / \mathrm{L}, \mathrm{pH} 6.4 / 6 \%$ acetonitrile) and elution was performed by using a gradient from solvent $A$ to solvent $\mathrm{B}\left(40 \% \mathrm{H}_{2} \mathrm{O} / 60 \%\right.$ acetonitrile) as described in Table 1. Both the column and solvents were maintained at $38 \mathrm{C}$. The flow rate was $1.0 \mathrm{~mL} / \mathrm{min}$ and absorbency was recorded at $254 \mathrm{~nm}$.

\section{N-terminal Sequencing}

The N-terminal amino acid sequence was determined using an Applied Biosystems model $477 \mathrm{~A}$ sequencer with on-line identification of the phenyl thiohydantoin derivatives. Reagents used for sequencing were purchased from 
Perkin Elmer (Paris Nord II, France). The amino acid sequences obtained were searched in the PCGen database and the NCBI, using the Blast network service.

TABLE 1.

ELUTION GRADIENT USED FOR

PHENYLTHIOCARBAMYL AMINO ACIDS SEPARATION

\begin{tabular}{|c|c|c|c|}
\hline time (min) & Flow rate $(\mathrm{mL} / \mathrm{min})$ & solvent A (\%) & solvent B (\%) \\
\hline 0 & 1 & 100 & 0 \\
\hline 1 & 1 & 100 & 0 \\
\hline 11 & 1 & 54 & 46 \\
\hline 11.5 & 1 & 0 & 100 \\
\hline 12.5 & 1 & 0 & 100 \\
\hline 13 & 1.5 & 0 & 100 \\
\hline 13.5 & 1.5 & 100 & 0 \\
\hline 21 & 1.5 & 100 & 0 \\
\hline
\end{tabular}

\section{Isoelectric Focusing}

Isoelectric focusing was performed on ready-to-use gels (Serva, Gagny, France) in the $\mathrm{pH}$ range 3-10. Isoelectric focusing was achieved at 4C on a 2117 Multiphor II apparatus (LKB, Bromma, Sweden), at a constant current of $7 \mathrm{~mA}$.

\section{Peptic Hydrolysis of Whey Proteins}

Since $\beta$-lactoglobulin is particularly resistant to peptic hydrolysis (Reddy $e t$ al. 1988), to determine its presence, hydrolysis of whey proteins was carried out essentially as described by Kinekawa and Kitabatake (1996). The $\mathrm{pH}$ of a whey protein solution $(70 \mathrm{mg} / \mathrm{mL}$ ) was adjusted to 2.0 by addition of $1 \mathrm{~N} \mathrm{HCl}$, and the solution was preincubated at $37 \mathrm{C}$ for $10 \mathrm{~mm}$. The enzymatic reaction was carried out at 37C, during $1 \mathrm{~h}$, by using an enzyme (pepsin A from porcine stomach EC. 3.4.23.1, 3400 units per mg protein, Sigma) / substrate ratio of 1 / $200(\mathrm{w} / \mathrm{w})$. The reaction was stopped by adjusting the $\mathrm{pH}$ to 8.0 with $1 \mathrm{~N}$ $\mathrm{NaOH}$. The reaction mixture was analyzed by size-exclusion chromatography on a TSKgel G 2000 SWXL column $(7.8 \mathrm{~mm}$ i.d. $\times 30 \mathrm{~cm})$. The column was equilibrated, and the sample eluted with a $50 \mathrm{mM}$ Tris/ $\mathrm{HCl}, \mathrm{pH} 8.0$ buffer at room temperature. The flow rate was $0.3 \mathrm{~mL} / \mathrm{min}$, and the absorbency was measured at $280 \mathrm{~nm}$. The column was calibrated with low molecular mass markers (Sigma, Saint Quentin Fallavier, France). 


\section{RESULTS AND DISCUSSION}

\section{Separation of Whey Proteins of Species Bovidae}

Whey proteins of cow, yak and khainak were separated by anion exchange chromatography on DEAE-Sephacel using a stepwise $\mathrm{NaCl}$ gradient (Fig. 1). The elution profiles obtained with whey of yak and khainak were similar to that obtained with bovine whey. The different fractions collected were analyzed by SDS-PAGE. As shown in Fig. 2, $\alpha$-lactalbumin was eluted at $0.1 \mathrm{M} \mathrm{NaCl}$ for cow, yak and khainak whey. $\beta$-Lactoglobulin was eluted at $0.15 \mathrm{M} \mathrm{NaCl}$ for cow, yak and khainak. As can be observed in Fig. 2, $\beta$-lactoglobulin of yak and khainak co-eluted with a protein of higher molecular mass. Serum albumins were collected in fractions 2, 2 and 3 for cow, yak and khainak, respectively. The major fractions were purified further by RP-HPLC and identified by their amino acid composition, determined after acid hydrolysis (Table 2). The obtained data for $\alpha$-lactalbumin and $\beta$-lactoglobulin of yak and khainak agree well with those of their bovine counterpart.

\section{Separation of Camel Whey Proteins}

By chromatography on HQ-Poros, whey proteins from Camelus bactrianus and Camelus dromedarius were separated into 7 fractions (Fig. $3 \mathrm{~A}$ and B). As observed by PAGE (Fig. 4), serum albumin was eluted in fraction 5 for both Camelus bactrianus and Camelus dromedarius. Analysis by SDS-PAGE shows that $\alpha$-lactalbumin was eluted in fraction 2 for Camelus bactrianus and Camelus dromedarius. It was further fractionated by FPLC, using a linear gradient of $\mathrm{NaCl}$ from 0 to $1 \mathrm{M}$, prior to a final purification by RP-HPLC. Two resulting fractions were analyzed by SDS-PAGE and IEF (Fig. 5). Their amino acid composition was determined (Table 3 ) and the first $23 \mathrm{~N}$-terminal amino acid residues were sequenced (Table 4). These results confirmed existence in milk of Camelus bactrianus of two forms of $\alpha$-lactalbumin, as seen previously in milk of Camelus dromedarius (Conti et al. 1985), with a slight difference in their amino acid composition and isoelectric point (5.1 and 5.3, respectively), though identical molecular weights were observed according to their mobility in SDS-PAGE at pH 8.0. Conti et al. (1985) reported that the two forms of $\alpha$-lactalbumin in Camelus dromedarius whey differed at the first $\mathrm{N}$-terminal position. According to our sequence data, the two forms of $\alpha$-lactalbumin of Camelus bactrianus and Camelus dromedarius show no differences in the first 23 positions and their sequences were identical to $\alpha$-lactalbumin of Camelus dromedarius (Beg et al. 1985) and of llama (Cantisani et al. 1990). The presence of a small amount of a third $\alpha$-lactalbumin in fractions eluted at a higher molarity of $\mathrm{NaCl}$ (more than $0.2 \mathrm{M}$ ) on anion-exchange chromatography of Camelus bactrianus whey was also observed. The $23 \mathrm{~N}$-terminal amino acid 

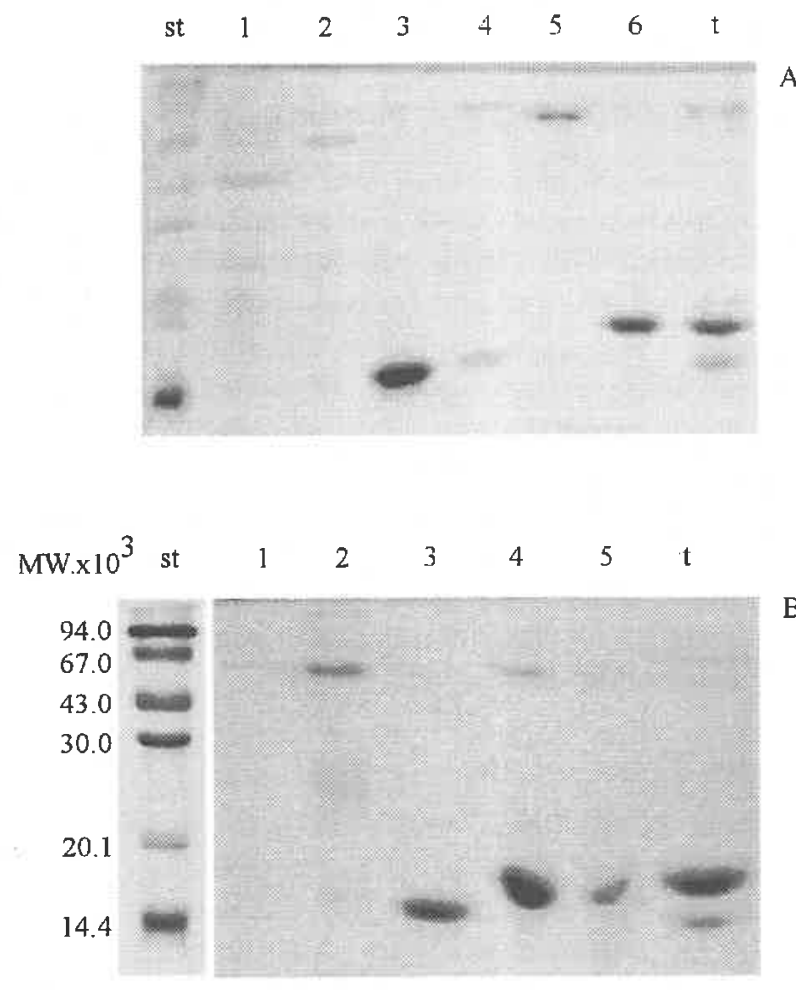

B

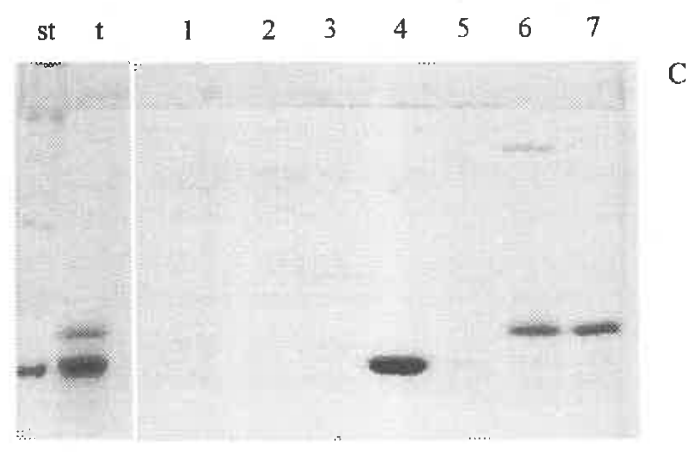

FIG. 2. SDS-PAGE OF BOVINE (A), YAK (B), AND KHAINAK (C) WHEY PROTEIN FRACTIONS OBTAINED BY DEAE-SEPHACEL CHROMATOGRAPHY

(A) 1 to 6 are fractions 1 to 6 , respectively. (B) 1 to 5 are fractions 1 to 5 , respectively.

(C) 1 to 7 are fractions 1 to 7 , respectively. $t$ is total cow, yak and khainak whey proteins.

st. is molecular mass standards. All gels were stained with Coomassie Blue. 


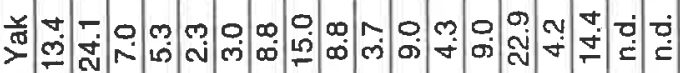

里

売

荇

듷

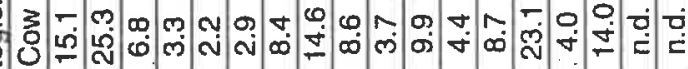

జ̛

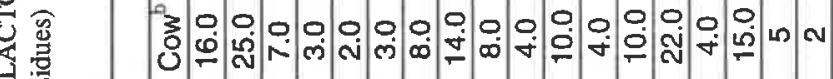

是令

ชั

岁

Z

㝵

8

$\sum_{0}^{0}$

TL

> $=$ 向

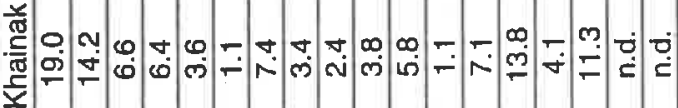

흘

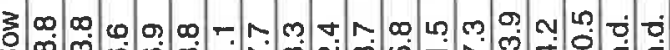

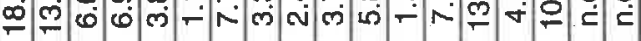

㫕

3.

尝

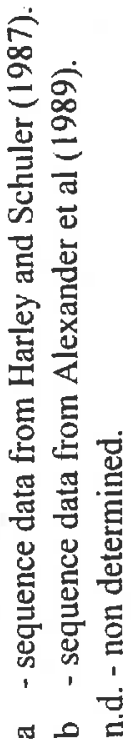



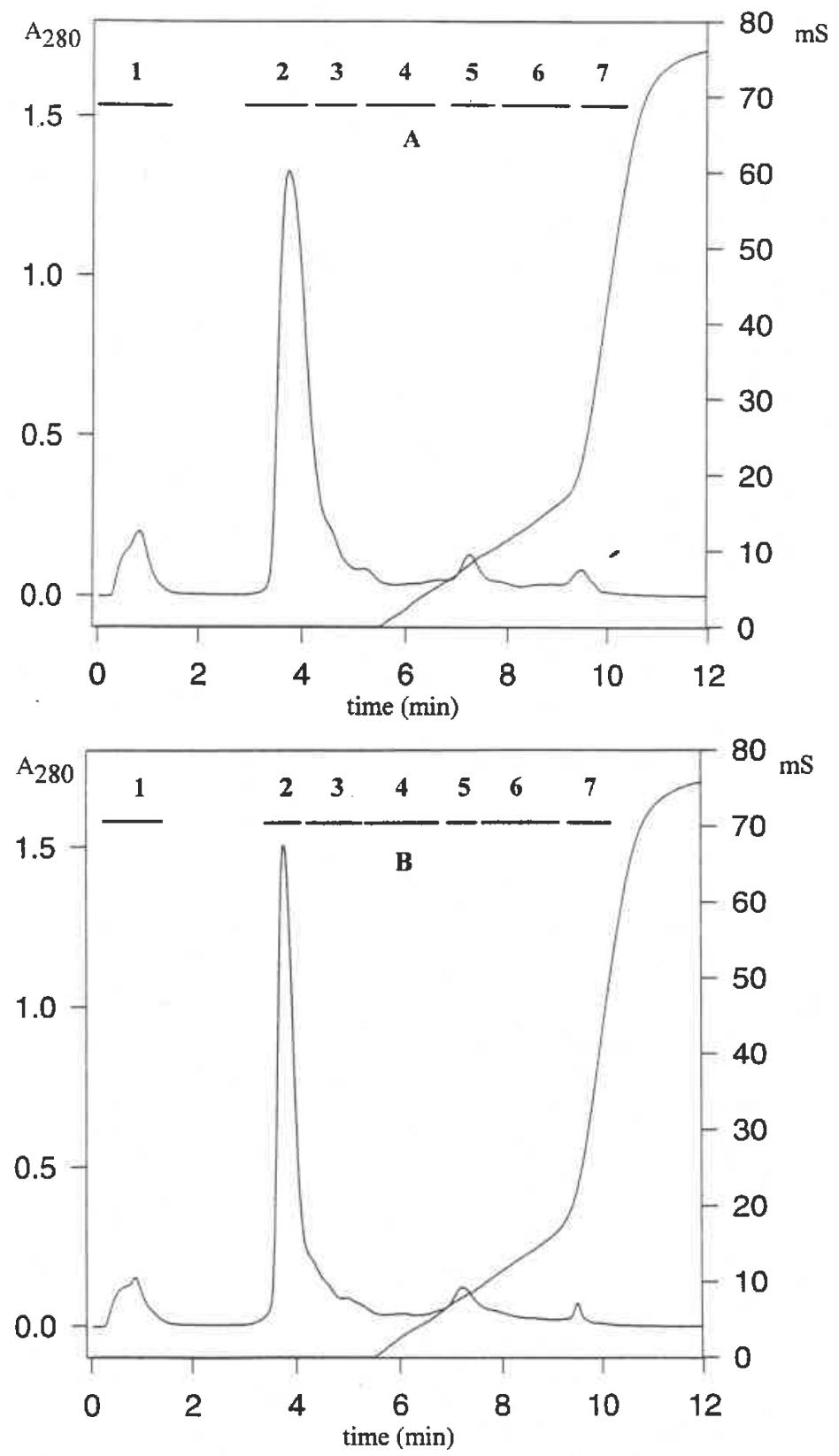

FIG. 3. SEPARATION OF TOTAL WHEY PROTEINS OF CAMELUS BACTRIANUS (A) AND CAMELUS DROMEDARIUS (B) BY HIGH PERFUSION ION-EXCHANGE CHROMATOGRAPHY ON HQ POROS $(20 \mu)$ COLUMN 1 to 7 are collection zones. $\mathrm{mS}$, conductivity. 


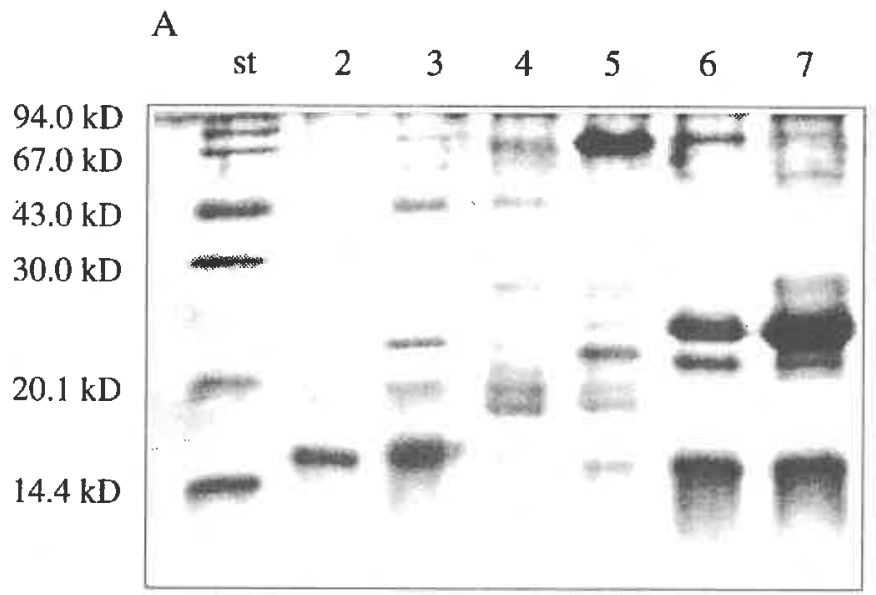

B

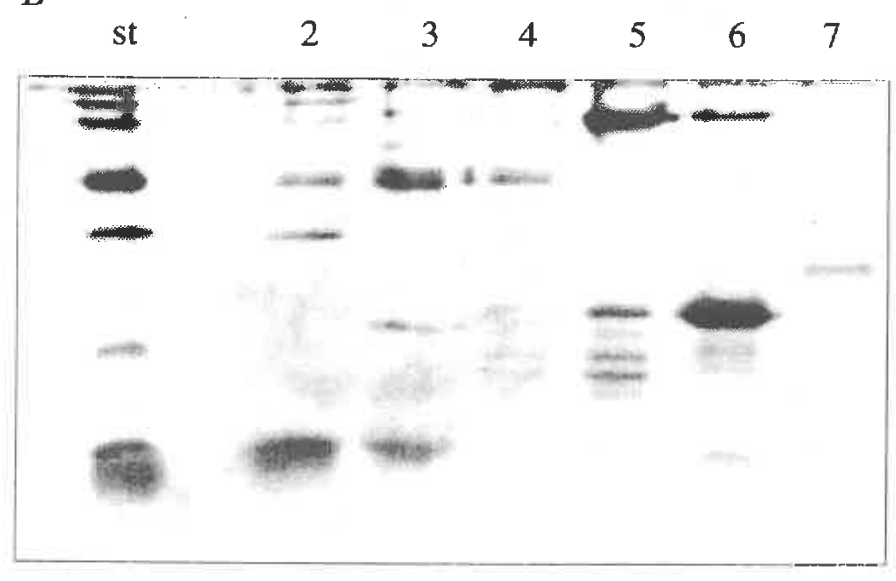

FIG. 4. SDS-PAGE PATTERNS OF CAMELUS BACTRIANUS (A) AND CAMELUS DROMEDARIUS (B) WHEY PROTEIN FRACTIONS OBTAINED BY HIGH PERFUSION ION-EXCHANGE CHROMATOGRAPHY ON HQ-POROS

st. is molecular mass standards. 2 to 7 are fractions 2 to 7 , respectively.

Gels were silver stained.

residues of this $\alpha$-lactalbumin had an identical sequence to two other forms. It is likely that milk of Camelus bactrianus contains glycosylated forms of $\alpha$-lactalbumin, as has been observed in cow (about $5 \%$ of total quantity of $\alpha$-lactalbumin) and in llama whey (Cantisani et al. 1990). To confirm this 
suggestion, the double-staining technique for glycoproteins (with Schiff's reagent) and protein was applied to the SDS-PAGE (data not shown). Unfortunately, the three bands corresponding to the three different forms of Camelus bactrianus and Camelus dromedarius $\alpha$-lactalbumin gave no visible band with Schiff's reagent. This could be due to the selectivity of the Schiff's reagent for reducing sugars.

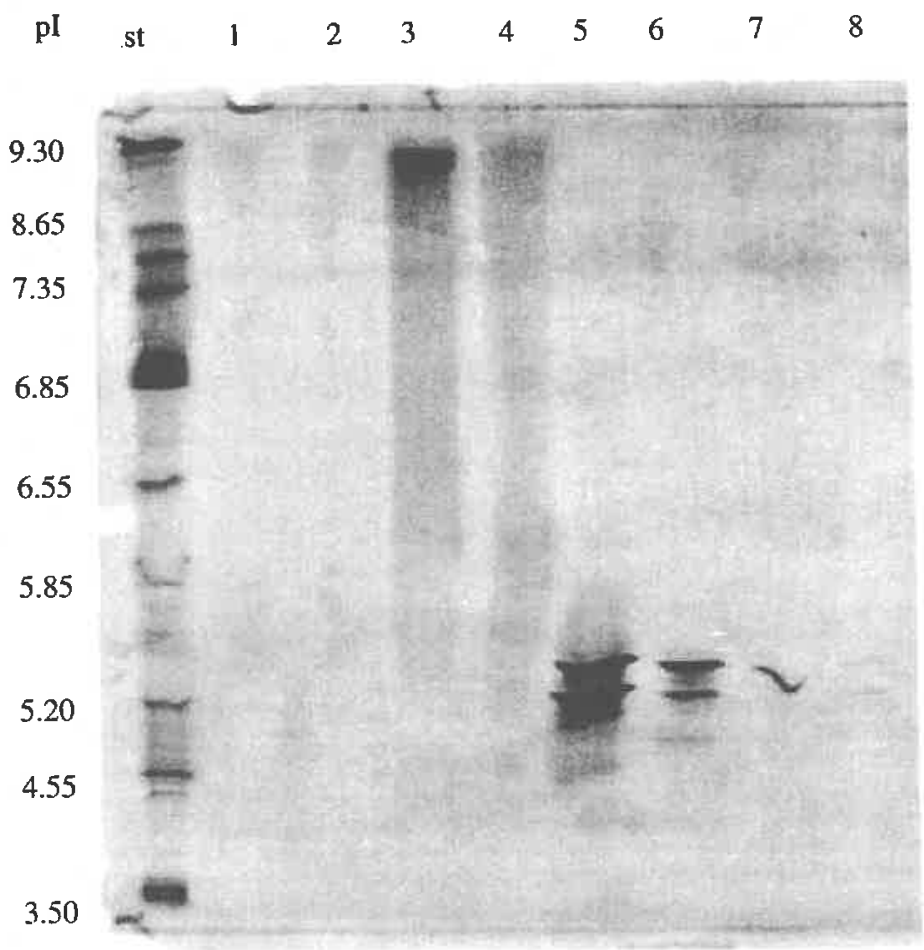

FIG. 5. ISOELECTRIC FOCUSING OF WHEY PROTEINS OBTAINED BY HIGH PERFUSION ION-EXCHANGE CHROMATOGRAPHY

1 and 4: whey basic protein (fractions 2 and 3, respectively) from Camelus dromedarius, 2 and 3: whey basic protein (fractions 2 and 3, respectively) from Camelus bactrianus; 5 and 6: $\alpha$-lactalbumin A and B, respectively, from Camelus dromedarius; 7 and 8: $\alpha$-lactalbumin A and B, respectively, from Camelus bactrianus.

All the fractions obtained by anion-exchange chromatography on HQ-Poros of Camelus bactrianus and Camelus dromedarius whey proteins were evaluated by double immunodiffusion against anti-bovine $\beta$-lactoglobulin antiserum. Only 
the first fraction (eluted without $\mathrm{NaCl}$ ) gave a positive reaction with antiserum to bovine $\beta$-lactoglobulin. This fraction was purified further by cation-exchange chromatography on a HS-Poros $20 \mu$ column, at $\mathrm{pH} 7.5$, and 4 peaks were

TABLE 3.

AMINO ACID COMPOSITION OF CAMEL $\alpha$-LACTALBUMIN A AND B (values are residue/100 residues)

\begin{tabular}{|c|c|c|c|c|c|c|}
\hline & $\alpha-\operatorname{lac} A \mathrm{Bac}$ & $\alpha-$ lac B Bac & $\alpha-\operatorname{lac} A D r$ & $\alpha-\operatorname{lac}$ B Dr & $\alpha-\operatorname{lac} A D r^{*}$ & $\alpha-\operatorname{lac} B D r^{*}$ \\
\hline ASX & 21.7 & 21.1 & 21.0 & 20.6 & 23.1 & 22.6 \\
\hline GLX & 13.6 & 14.0 & 13.9 & 14.2 & 14.7 & 15.3 \\
\hline SER & 5.6 & 6.3 & 6.1 & 5.7 & 5.5 & 6.4 \\
\hline GLY & 7.3 & 7.3 & 7.5 & 7.0 & 7.8 & 7.6 \\
\hline HIS & 2.6 & 2.8 & 3.1 & 2.9 & 2.6 & 2.7 \\
\hline ARG & 2.8 & 3.0 & 3.0 & 2.8 & 2.8 & 2.3 \\
\hline THR & 4.2 & 4.7 & 4.3 & 4.5 & 5.3 & 5.9 \\
\hline ALA & 2.9 & 3.6 & 2.8 & 3.0 & 3.4 & 3.9 \\
\hline PAO & 1.3 & 2.1 & 1.3 & 1.6 & 1.4 & 1.6 \\
\hline TYR & 1.0 & 0.9 & 0.9 & 1.1 & 1.5 & 0.6 \\
\hline VAL & 1.8 & 2.0 & 1.8 & 1.9 & 1.5 & 2.6 \\
\hline MET & 2.1 & 1.3 & 1.8 & 1.8 & 2.4 & 2.3 \\
\hline ILE & 6.0 & 5.7 & 5.9 & 6.1 & 9.6 & 8.8 \\
\hline LEU & 10.4 & 9.9 & 10.0 & 10.1 & 11.8 & 14.5 \\
\hline PHE & 3.2 & 3.2 & 3.3 & 3.4 & 4.3 & 3.9 \\
\hline LYS & 13.3 & 13.6 & 13.2 & 13.5 & 12.9 & 12.0 \\
\hline CYS & n.d. & n.d. & n.d. & n.d. & 4.8 & 5.2 \\
\hline TRP & n.d. & n.d. & n.d. & n.d. & n.d. & n.d. \\
\hline
\end{tabular}

* - data from Conti et al (1985).

n.d.- non determined amino acid.

Bac - Camelus bactrianus.

Dr - Camelus dromedarius.

TABLE 4.

N-TERMINAL SEQUENCES OF CAMELUS BACTRIANUS $\alpha$-LACTALBUMIN A, B AND C. COMPARISON WITH CAMELUS DROMEDARIUS A (BEG ET AL. 1985) AND LLAMA GLAMA $\alpha$-LACTALBUMINS A, B AND C

(Cantisani et al. 1990)

Camelus bactrianus (A, B and C) Camelus dromedarius $\mathrm{A}$

Llama glama $L$ (A, B and C)

Camelus dromedarius $\alpha$-lac $\mathrm{A}^{*}$

Camelus dromedarius $\alpha$-lac $\mathrm{B}^{*} \quad \mathrm{E} Q F$

* - from sequence data Conti et al (1985).

$\mathrm{X}$ - non determined.
KQFTK XKLSD ELKGM NGNGG ITL KQFTK CKLSD ELKGM NGNGG ITL KQFTK CKLSD ELKGM NGNGG ITL 
collected (data not shown). As observed by SDS-PAGE (Fig. 6), the first peak contained several proteins with molecular masses of about $14.0 \mathrm{kDa}, 16.0 \mathrm{kDa}$, $43.0 \mathrm{kDa}$ and $54.0 \mathrm{kDa}$. The second and the third peak contained a single protein with molecular mass of approximately $20 \mathrm{kDa}$. Determination of its amino acid composition (Table 5) and its isoelectric focusing (Fig. 5) showed that it is a basic protein. The $\mathrm{N}$-terminal sequence of this camel whey basic
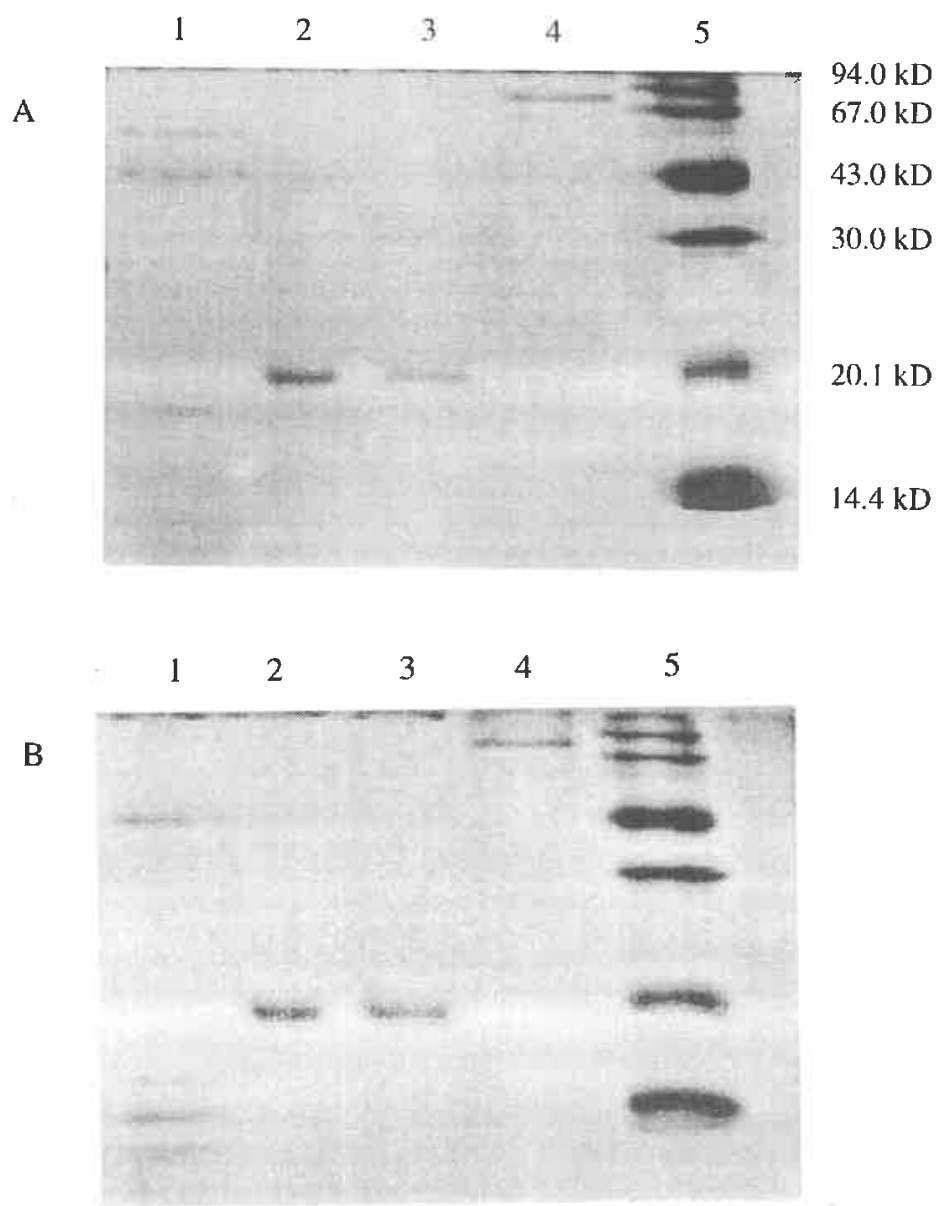

FIG. 6. SDS-PAGE OF FRACTIONS 1 TO 4 ISSUED FROM CHROMATOGRAPHY ON

HS-POROS OF FRACTION 1 OBTAINED AFTER SEPARATION ON HQ-POROS CHROMATOGRAPHY

Camelus bactrianus (A) and Camelus dromedarius (B). 5 is molecular mass standards.

Gels were silver stained. 
TABLE 5.

AMINO ACID COMPOSITION OF CAMELUS BACTRIANUS (BWBP) AND CAMELUS DROMEDARIUS (DWBP) WHEY BASIC PROTEIN

(values are residue/100 residues)

\begin{tabular}{|c|c|c|c|c|c|}
\hline & BWBP & DWBP & & BWBP & DWBP \\
\hline ASX & 8.2 & 7.9 & TYR & 1.3 & 1.6 \\
\hline GLX & 10.5 & 10.7 & VAL & 7.5 & 7.5 \\
\hline SER & 7.6 & 7.1 & MET & 0.5 & 0.6 \\
\hline GLY & 11.3 & 10.8 & ILE & 4.0 & 4.0 \\
\hline HIS & 4.0 & 3.9 & LEU & 8.2 & 7.9 \\
\hline ARG & 11.1 & 11.2 & PHE & 1.7 & 1.5 \\
\hline THR & 4.2 & 4.5 & LYS & 1.8 & 1.9 \\
\hline ALA & 10.2 & 9.8 & CYS & n.d. & n.d. \\
\hline PRO & 8.0 & 7.6 & TRP & n.d. & n.d. \\
\hline
\end{tabular}

n.d.- non determined.

protein (CWBP) is shown in Table 6. Compared with known sequences of camel and llama milk proteins, CWBP showed no homology: The presence of a "heterogeneous camel milk whey noncasein protein" and a "llama whey protein with unknown function" was already reported (Beg et al. 1987; Cantisani et al. 1990). CWBP may belong to this category of proteins. The fourth peak, according to SDS-PAGE (Fig. 6; MW: $78.0 \mathrm{kDa}$ ) and N-terminal sequence (Table 7) contained lactoferrin. The first $20 \mathrm{~N}$-terminal amino acid sequence of Camelus bactrianus and Camelus dromedarius lactoferrin showed $56 \%$ homology with lactoferrin of sheep and pig.

In order to detect the presence of $\beta$-lactoglobulin in the whey of Camelus bactrianus and Camelus dromedarius, total whey was submitted to a proteolysis by pepsin. Since bovine $\beta$-lactoglobulin is not susceptible to pepsin, even after $40 \mathrm{~h}$ hydrolysis (Dalgalarrondo et al. 1995), if this protein exists in milk of Camelus bactrianus and Camelus dromedarius a peak should be obtained by size-exclusion chromatography in the molecular weight range $16-20 \mathrm{kDa}$. Its absence (data not shown) after peptic action confirms that milk from Camelus bactrianus and Camelus dromedarius is devoid of $\beta$-lactoglobulin. The observed cross-reactivity of the proteins contained in the first peak eluted by DEAE-Sephacel chromatography with antiserum of bovine $\beta$-lactoglobulin, can be explained by the presence of lactoferrin in this peak. Brignon et al. (1985) have reported that the bovine lactoferrin may give positive cross-reactivity with antiserum to $\beta$-lactoglobulin. 


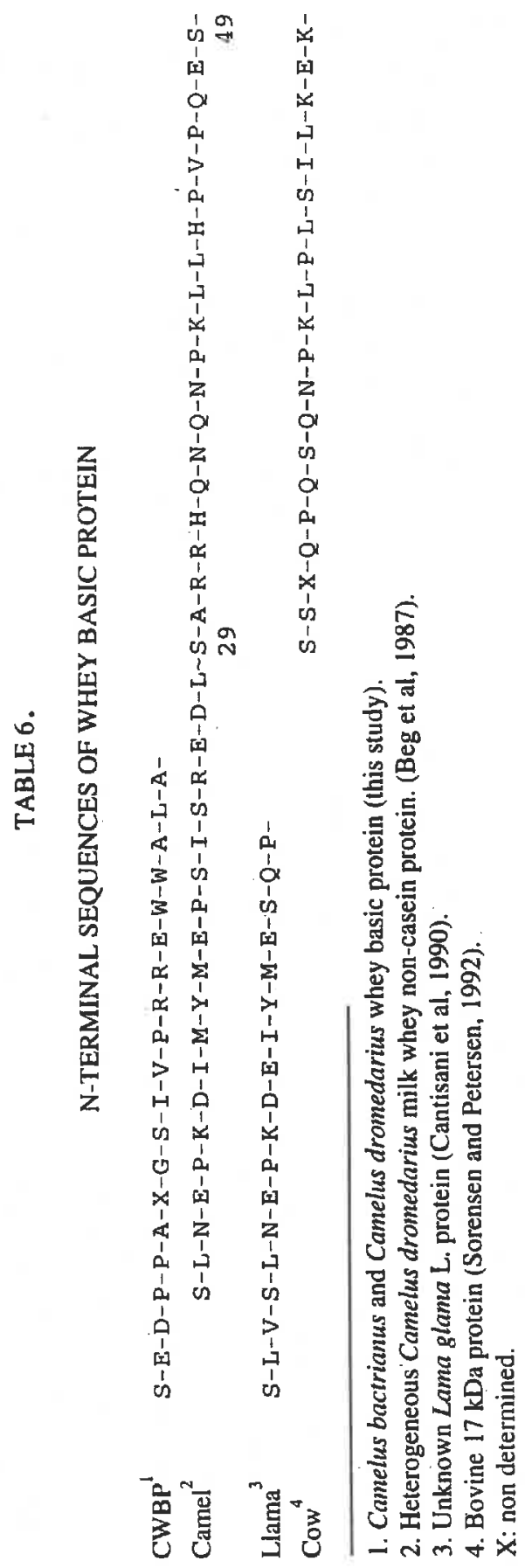


TABLE 7.

N-TERMINAL SEQUENCES OF CAMELUS BACTRIANUS LACTOFERRIN. COMPARISON WITH COW AND PIG LACTOFERRIN

Camelus bactrianus

Bos taurus

Sus crofa L.
A $-\mathrm{X}-\mathrm{K}-\mathbf{R}-\mathrm{X}-\mathrm{V}-\mathbf{R}-\mathrm{W}-\mathrm{X}-\mathrm{T}-\mathrm{T}-\mathbf{S}-\mathrm{P}-\mathrm{A}-\mathrm{E}-\mathrm{S}-\mathrm{X}-\mathbf{K}-\mathrm{X}-\mathrm{A}-$

A- $-\mathrm{P}-\mathrm{R}-\mathrm{K}-\mathrm{N}-\mathrm{V}-\mathrm{R}-\mathrm{W}-\mathrm{C}-\mathrm{T}-\mathrm{I}-\mathrm{S}-\mathrm{Q}-\mathrm{P}-\mathrm{E}-\mathrm{W}-\mathrm{F}-\mathrm{K}-\mathrm{C}-\mathrm{R}-$

A-P-R-K-G-V-R-W-C-T-I-S-T-A-E-Y-S-K-C-R-

$\mathrm{X}$ - non determined.

\section{CONCLUSION}

Results of this study indicate that the whey of Camelus bactrianus contains a major protein, $\alpha$-lactalbumin, existing in three different forms, as in llama whey. These three different forms of $\alpha$-lactalbumin have identical sequences of the first $23 \mathrm{~N}$-terminal amino acids. The first two forms eluted together (at $0.1 \mathrm{M} \mathrm{NaCl}$ ) during DEAE-Sephacel chromatography and migrated in the same region on SDS-PAGE. They could be separated by isoelectric focusing and/or by anion exchange chromatography, using columns with high resolving power. The third form eluted at a higher $\mathrm{NaCl}$ concentration (about $0.15 \mathrm{M}$ ) and during SDS-PAGE showed lower mobility (higher apparent molecular weight) than the other two forms. An unknown protein, named camel whey basic protein (CWBP) is present in whey of Camelus bactrianus. It showed no obvious structural similarities with other well characterized milk and nonmilk proteins.

Whey proteins display excellent nutritional properties and are used as protein supplement in the formulation of an enteral dietary product for patients with pulmonary disease or renal insufficiency (Trimbo 1992). As it is known, the presence of $\beta$-lactoglobulin in milk may cause a number of problems both in food processing and nutrition. Particularly, the compact globular structure of $\beta$-lactoglobulin makes it difficult to digest (Chobert et al. 1997). $\beta$-Lactoglobulin is responsible for some of the observed allergies to cow's milk (Asselin et al. 1988). Since camel milk is devoid of $\beta$-lactoglobulin (or contains a very small amount of it), it could be interesting as a new raw material for infant formula and for nutrition in countries where these animals thrive.

\section{ACKNOWLEDGMENTS}

We thank Dr. Hanitra Rabesona (INRA-LEIMA, Nantes, France) for sequence determinations and Dr. Didier Levieux (INRA-SRV, Theix, France) for immunological experiments. 


\section{REFERENCES}

ALEXANDER, L.J., HAYES, G., PEARSE, M.J., BEÁTTIC, C.W., STEWART, A.F., WILLIS, I.M. and MACKINLAY, A.G. 1989. Complete sequence of the bovine beta-lactoglobulin cDNA. Nucleic Acids Res. 17, 6739 .

ASSELIN, J., AMIOT, J., GAUTHIER, S.F., MOURAD, W. and HERBERT, J. 1988. Immunogenicity and allergenicity of whey protein hydrolysates. J. Food Sci. 53, 1208-1211.

BEG, O.U., VAN BAHR-LINDSTROM, H., ZAIDI, Z.H. and JORNVA, H. 1984. A small camel milk protein rich in cystein/half-cystein. Biosci. Reports 4, 1065-1070.

BEG, O.U., VAN BAHR-LINDSTROM, H., ZAIDI, Z.H. and JORNVAL, H. 1985. The primary structure of $\alpha$-lactalbumin from camel milk. Eur. J. Biochem. 147, 233-239.

BEG, O.U., VAN BAHR-LINDSTROM, H., ZAIDI, Z.H. and JORNVAL, H. 1986. Characterization of a camel milk protein rich in proline identifies a new $\beta$-casein fragment. Regulatory Peptides 15, 55-62.

BEG, O.U., VAN BAHR-LINDSTROM, H., ZAIDI, Z.H. and JORNVAL, H. 1987. Characterization of a heterogeneous camel milk whey non-casein protein. Eur. J. Biochem. 216, 270-274.

BELL, K. and McKENZIE, H.A. 1964. $\beta$-Lactoglobulins. Nature 204, 1275-1279.

BELL, K., McKENZIE, H.A., MULLER, V., ROGERS, C. and SHAW, D.C. 1981. Equine whey proteins. Comp. Biochem. Physiol. 68B, 225-236.

BIDLINGMEYER, B.A., COHEN, S.A. and TARVIN, T.L. 1984. Rapid analysis of amino acids using precolumn derivatization. J. Chromatogr. 336, 93-104.

BRIGNON, G., CHTOUROU, A. and RIBADEAU DUMAS, B. 1985. Does $\beta$-lactoglobulin occur in human milk. J. Dairy Sci. 55, 249-254.

CANTISANI, A., NAPOLITANO, L., GIUFFRIDA, M.G. and CONTI, A. 1990. Direct identification and characterisation of llama (Lama glama L.) whey proteins by microsequencing after Western blotting. J. Biochem. Biophys. Methods 21, 227-236.

CHOBERT, J.M., BRIAND, L., DUFOUR, E., DIB, R., DALGALARRONDO, M. and HAERTLE, T. 1997. How to increase $\beta$-lactoglobulin susceptibility to peptic hydrolysis? J. Food Biochemistry 20 , 439-462.

CONTI, A., GODOVAC-ZIMMERMAN, J., NAPOLITANO, L. and LIBERATORI, J. 1985. Identification of two $\alpha$-lactalbumin from Somali camel milk (Camelus dromedarius). Milchwissenschaft 40, 673-675. 
DALGALARRONDO, M., DUFOUR, E., CHOBERT, J.M., BERTRANDHARB, C. and HAERTLE, T, 1995. Proteolysis of $\beta$-lactoglobulin and $\beta$-casein by pepsin in ethanolic media. Int. Dairy J. 5, 1-14.

GROSCLAUDE, F., MAHE, M.-F. and ACCOLAS, J.-P. 1982. Note sur le polymorphisme génétique des principales lactoprotéines de bovins et de yaks Mongols. Ann. Génét. Sél. Anim. 14, 545-550.

GROSCLAUDE, F., MAHE, M.-F., MERCIER, J.-C., BONNMAIRE, J. and TEISSIER, J.H. 1976. Polymorphisme des lactoprotéines de Bovidés Népalais. Ann. Génét. Sél. Anim. 8, 467-479.

GROVES, M.L., DOVER, H.J. and FARREL, JR., H.M. 1992. Re-examination of the polymeric distribution of $k$-casein isolated from bovine milk. J. Prot. Chem. 11, 21-28.

HARLEY, W.L. and SCHULER, L.A. 1987. Molecular cloning and nucleotide sequence of a bovine $\alpha$-lac cDNA. Gene $61,119-122$.

KESSLER, E. and BREW, K. 1970. The whey proteins of pig's milk. Isolation and characterisation of a $\beta$-lactoglobulin. Biochem. Biophys. Acta 200, 449-458.

KIM, Y.A., CHISM, G.W. and MANGINO, M.E. 1987. Determination of the $\beta$-lactoglobulin, $\alpha$-lactalbumin and bovine serum albumin of whey protein concentrates and their relationship to protein functionality. J. Food Sci. 52, 124-127.

KINEKAWA, Y. and KITABATAKE, N. 1996. Purification of $\beta$-lactoglobulin from whey protein concentrate by pepsin treatment. J. Dairy Sci. 79, 350-356.

LAEMMLI, U.K. 1970. Cleavage of structural proteins during the assembly of the head of Bacteriophage T4. Nature 227, 680-685.

LIBERATORI, J., GUIDETTI, M.L., CONTI, A. and NAPOLITANO, L. 1979. $\beta$-lactoglobulins in the mammary secretions of camel (Camelus dromedarius) and she-ass. Immunological detection and preliminary physico-chemical characterisation. Boll. Soc. It. Biol. Sper. LV, 13691373.

McDOUGALL, E.I. and STEWART, J.C. 1976. The whey proteins of the milk of red deer (Cervus claphus L.). Biochem. J. 153, 647-655.

NESTERENKO, M.V., TILLEY, M. and UPTON, S.J. 1994. A simple modification of Blum's silver stain method allows for 30 minute detection of proteins in polyacrylamide gels J. Biochem. Biophys. Methods 28, 239-342.

OCHIRKHUYAG, B., CHOBERT, J.M., DALGALARRONDO, M., CHOISET, Y. and HAERTLE, T. 1997. Characterization of caseins from mongolian yak, khainak and bactrian camel. Lait 77, 601-613.

PALMER, A.H. 1934. The preparation of a crystalline globulin from the albumin fraction of cow's milk. J. Biol. Chem. 104, 359-372. 
PEARCE, R.J. 1983. Analysis of whey proteins by high performance liquid chromatography. Aust. J. Dairy Technol. 38, 114-117.

PREAUX, G., BRAUNITZER, G., SCHRANK, B. and STANGL, A. 1979. The amino acid sequence of goat $\beta$-lactoglobulin. Hoppe Seyler's $Z$. Physiol. Chem. 360, 1595-1604.

REDDY, M.I., KELLA, N.K.D. and KINSELLA, J.E. 1988. Structural and conformational basis of the resistance of $\beta$-lactoglobulin to peptic and chymotryptic digestion. J. Agric. Food Chem. 36, 737-741.

SORENSEN, E.S. and PETERSEN, T.E. 1992. Purification and characterization of three proteins isolated from the proteose peptone fraction of bovine milk. J. Dairy Res. 60, 189-197.

TRIMBO, S.L. 1992. US PATENT US 5, 116819.

VILOTTE, J.L. and SOULIER, S. 1992. Isolation and characterization of the mouse $\alpha$-lac-encoding gene: interspecies comparison, tissue- and stage-specific expression. Gene 119, 287-292.

ZALL, R.R. 1992. Whey and lactose processing of $\alpha$-lactalbumin. In Sources and Composition of Whey and Permeate, (J.G. Zadow, ed.) Elsevier, London. 